\title{
OBITUARIES
}

For the full versions of articles in this section see bmj.com

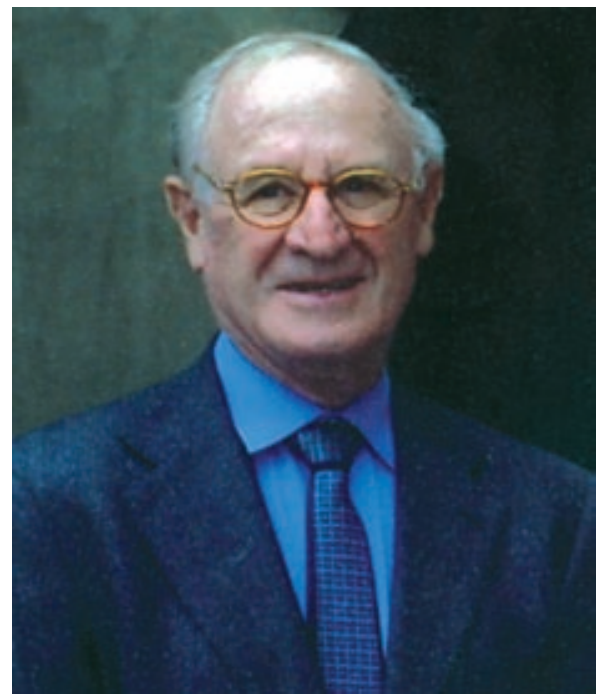

\section{Victor Wynn}

\section{Pioneer of metabolic studies of heart disease and founder of an institute}

Victor Wynn was one of the first people to specialise in the study of metabolism and established a research laboratory at St Mary's Hospital, followed by founding and funding the Cavendish Institute, an independent establishment that was later renamed the Wynn Institute. He pioneered electrolyte measurement, now a routine part of post-surgical care and essential to the treatment of kidney failure.

He had strong views-some would say a bee in his bonnet-about the dangers of the contraceptive pill. He was one of the first to recognise the importance of risk factors for cardiovascular disease and their modification. He also undertook the first large studies of the effects of the pill on sugar and fat metabolism, and the changes he observed resembled those seen in men at increased risk of heart disease. He published his findings in the Lancet in 1966, creating a furore. He was interviewed on the Frost Programme, and the resulting scare led the then health secretary, Richard Crossman, to accuse Wynn of making "10 000 women pregnant on a single night."
He established two charities, the Heart Disease and Diabetes Research Trust and the Atherosclerosis Research Institute, which have jointly raised $£ 15$ m.

When he arrived in 1950 to work in the surgery department at St Mary's, the importance of electrolyte measurement was barely recognised and metabolic medicine did not exist as a clinical specialty. Wynn changed all that.

Wynn was born in Melbourne into a well-known wine growing family. From Wesley College, Melbourne, he went to Melbourne University, and did his clinical training and house jobs at the Royal Melbourne Hospital, qualifying in 1944.

He was a medical officer in the Australian air force from 1945 to 1948 and later in his career, from 1963, was a civilian consultant to the Royal Air Force.

He returned to Melbourne as a research fellow researching electrolyte measurement, which in those days was not a normal part of medical practice. He came to St Mary's in 1950, rising to junior lecturer in 1953; consultant in clinical biochemistry in 1954, and reader in human metabolism in 1960 . He was made Britain's first professor of human metabolism in 1969.

Wynn displayed a can-do Australian spirit in setting up his first laboratory at St Mary's, commandeering unused hospital space and acquiring the components he needed for his electrolyte measurements from local shops. This entrepreneurial directness, which characterised his approach to research, set him apart from, and at times, at odds with, more conventional colleagues.

He was very good at raising funds from wealthy philanthropists, and often urged his colleagues to emulate him. At his instigation, in 1953 the hospital approved plans to set up a metabolic unit, though it took 16 years to create a 10 -bed metabolic ward. The laboratory facilities were insufficient, but, despite a squeeze on medical education and research, the university grants committee approved a small capital grant to buy the former British Railways stables and rebuild them as a metabolic unit. Money was raised from ex-patients and from Dr Leonard Simpson, the hospital's consultant endocrinologist, whose family owned the department store in Piccadilly (the model for the television comedy series Are You Being Served?). Wynn got the Turriff construction company to construct the building free of charge.

The new laboratories were called the Mint Wing, and by the time it opened Wynn's interests had turned from electrolytes and renal failure to endocrinology and the long term administration of synthetic steroids. When anabolic steroids were new in the 1960s and were known to prevent muscle wasting and aid recovery from surgery, Wynn showed that they had potent side effects in fat and sugar metabolism, and cautioned against their use. In 1966 he predicted that women taking the pill would be at increased risk of heart attack, and epidemiological studies showed him to be right. In the 1970s he urged cardiologists to pay attention to patients' cholesterol concentrations, and in the 1980s he called on the food industry to sell "heart friendly" products.

During this time he was a consultant to the Royal Air Force, British Airways, and the Civil Aviation Authority.

On his retirement from St Mary's, aged 66 , he used his energy and fundraising skills to found the Cavendish Institute, located some distance from the hospital and affiliated to the UK National Heart and Lung Institute. It has since been renamed the Wynn Institute and is affiliated to Imperial College.

In 2001 in Melbourne the Wynn Department of Metabolic Cardiology was opened. In 2006 Wynn was made a Fellow of Imperial College. He suffered from heart disease for the last 30 years of his life.

He leaves a wife, Marianne, emeritus professor of German, and a daughter. Caroline Richmond

Victor Wynn, former professor of human metabolism London University, and chairman Wynn Institute for Metabolic Research (b 1920; q Melbourne 1944; MD, FRCP, FRCPath), d 6 October 2006. 


\section{Patrick John Murray Brock}

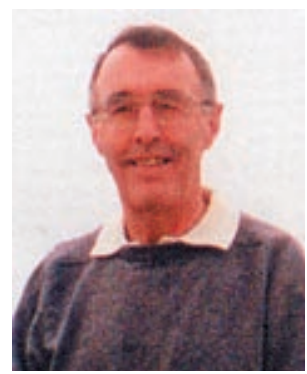

Former consultant anaesthetist Royal Berkshire and Battle Hospitals NHS Trust (b 1941; q Cardiff 1967; FRCA), died from a cerebral haemorrhage on 22 November 2006.

Patrick John Murray Brock took up his anaesthetics post in Reading in 1975, and he remained there for more than 25 years. He was especially interested in obstetric anaesthesia, and he went on to supervise the extensive obstetric anaesthesia service in Reading. He had enjoyed athletics as a student, and throughout his career he continued to compete in marathons and half marathons. Patrick was much loved for his quiet wisdom and matchless sense of humour. He leaves a wife, Margaret; three children; and two grandchildren. E Young

\section{Bruce Henry Davies}

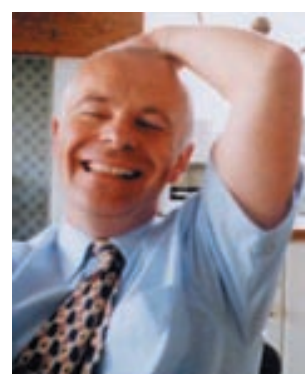

General practitioner and trainer Hutton Rudby, North Yorkshire (b 1957; q University College Hospital London 1981), died from lung cancer on 23 September 2006.

After doing a vocational training service scheme, Bruce Henry Davies became a general practitioner in 1986 and then a general practitioner trainer in 1989. Over the next 20 years he became a local legend in a small village practice. Although involved in computerisation from early on, both locally and nationally, he worked for 20 years without an appointment system. He was a trainer and course organiser for the local vocational training service for 12 years and was also a member of the Hambleton and Richmond primary care trust. He was a school governor and loved gardening and cooking; he had a passion for organic food, much of which he grew himself. He leaves a wife and three daughters.

David Hughes

Roger Higson

\section{John Drew Hamer}

Former consultant surgeon Queen Elizabeth Hospital, Birmingham (b Nuneaton 1935, q Birmingham 1960; BSc, ChM, FRCS), d 1 September 2005. After qualifying, John Drew Hamer worked as a general practitioner in Staffordshire. Realising general practice was not for him, he trained as a surgeon and was appointed senior lecturer in 1972 and then consultant surgeon at the Queen Elizabeth Hospital, Birmingham, in 1975. His interest in vascular surgery contributed to the development of the vascular unit. He was secretary of the West Midlands Surgical Society. He maintained his university connections as an honorary clinical senior lecturer. John was a skilled furniture maker, keen sailor, and chorister-he was chairman of the Bromsgrove Choral Society. He leaves a wife, Angela; two children; and five grandchildren.

Andrew J Hamer

John W L Fielding

\section{Sam Wystan Poshela Mhlongo}

Professor of family medicine MEDUNSA (b 1940; q Charing Cross, London, 1976; MSc, MRCGP), died in a car crash on 6 October 2006.

Sam Mhlongo opposed apartheid and was imprisoned on Robben Island, where he was close to

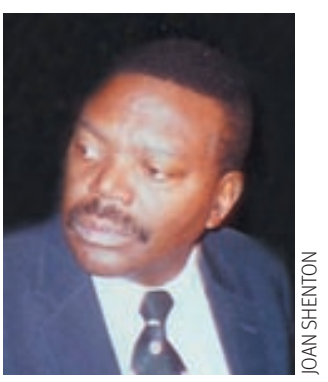

Nelson Mandela. In exile in London he studied medicine and became a general practitioner. In 1998 he returned to South Africa to a foundation chair at MEDUNSA (Medical University of Southern Africa, now University of Limpopo). President Mbeki appointed him adviser on family health with responsibilities for correcting historic problems and developing services in new communities in the Johannesburg area. One such problem was the different regional and sex related prevalance of HIV/ AIDS associated with inaccuracies in serological tests. Sam became known as a well-qualified African opponent of the pessimism of the pandemic of HIV/AIDS, using local wisdom in initiatives to overcome innate inequalities between the sexes, regions, and socioeconomic groups. He leaves a second wife, Maria Giacomin, and their two sons, and a first wife, Anne Morgan, and their daughter and two grandsons.

Gordon Stewart

Andrew Herxheimer

\section{John Kenyon (“Titus") Oates}

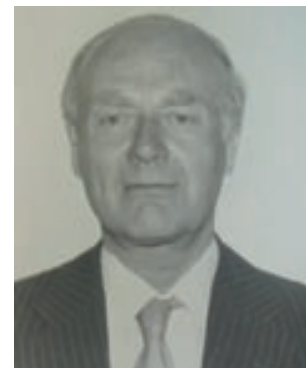

Former consultant in venereology Westminster Hospital, Addenbrooke's Hospital (b 1922; q London Hospital 1946; FRCP, MA), died from ischaemic heart disease complicated by motor neurone disease on 9 August 2006.
John Kenyon (“Titus") Oates developed his interest in venereology during the year he spent at Johns Hopkins Hospital, Baltimore as a Fulbright scholar. He aimed to take venereology out of the dark ages-from hospital basements into mainstream medicine-and put it on a scientific basis. His particular interests were herpes and Reiter's syndrome. A paperback, Herpes. The Facts, written for the general public, was one of the first books to address the myths surrounding this infection. As a teacher and lecturer Titus Oates excelled, and his interviews for radio were well received by producers and public alike. He leaves a wife, Sue; two children; and two grandchildren. David Rowen

Chris Sonnex

\section{John Stanley Mornington Zorab}

Former consultant anaesthetist and medical director Frenchay Hospital, Bristol (b 1929; q Guy's Hospital, London, 1957; FFARCS, DHMSA), d 17 July 2006.

John Zorab was appointed consultant at Frenchay in 1966. He helped create the intensive care unit and a nationally and internationally renowned anaesthetic department. His other achievements included helping to found the European Academy of Anaesthesia and the European diploma in anaesthesiology and intensive care. He was also on the council of the Association of Anaesthetists and the Board of the Faculty of Anaesthetists of the Royal College of Surgeons. He became president of the European section and later president of the World Federation of Societies of Anaesthesiology. In his latter years he became involved in hospital management at Frenchay, continuing for two years after retirement age. In retirement he studied and qualified in the history of medicine. He leaves a wife, Shirley, and four children. Peter Baskett, Peter Simpson, John Carter 